\title{
Magnesium: The Neglected Electrolyte? A Clinical Review
}

\author{
Pranev Sharma1, Christine Chung'2, Marcela Vizcaychipi ${ }^{1}$ \\ ${ }^{1}$ Magill Department of Anaesthesia, Chelsea \& Westminster Hospital, London, UK \\ ${ }^{2}$ Imaging \& Anaesthetics, Chelsea \& Westminster Hospital, London, UK \\ Email: pranev.sharma@doctors.org.uk
}

Received 7 May 2014; revised 7 June 2014; accepted 27 June 2014

Copyright (C) 2014 by authors and Scientific Research Publishing Inc.

This work is licensed under the Creative Commons Attribution International License (CC BY). http://creativecommons.org/licenses/by/4.0/

(c) (i) Open Access

\begin{abstract}
Magnesium, $\mathrm{Mg}^{2+}$, is the second most abundant intracellular cation after potassium and the fourth most abundant in the body. It was first isolated in 1808 by the English chemist, Sir Humphrey Davy. Magnesium is essential to numerous biochemical reactions. It modulates key physiological processes such as metabolic biochemistry, nucleic acid synthesis, receptor-binding and ion flux. The western diet falls short of the recommended daily allowance of $4.5 \mathrm{mg} / \mathrm{Kg} / \mathrm{day}$ and important dietary sources are seeds, grains, nuts and green vegetables. It is used as a therapeutic agent in a broad range of pathologies: neurological, cardiovascular, respiratory, gastrointestinal and obstetric. The pharmacokinetics and pharmacodynamics of magnesium, as a drug, are not well understood. Despite its fundamental importance to human physiology, it remains an electrolyte that is not routinely measured as part of the "urea \& electrolytes" test and is the most overlooked electrolyte deficiency in hospital inpatients. This review will summarise the importance of magnesium homeostasis, its pharmacological effects and clinical applications.
\end{abstract}

\section{Keywords}

Magnesium, Pharmacology, Pharmacodynamics, Pharmacokinetics, Physiology, Arrhythmias, Eclampsia, Pre-Eclampsia, Phaeochromocytoma

\section{Magnesium Intake and Regulation of Balance}

A normal adult has approximately $1000 \mathrm{mmol}$ of magnesium (22 - $26 \mathrm{~g})$, the majority of which is stored within the bone $(52.9 \%)$, followed by muscle (27\%) and soft tissue (19\%). Normal serum concentration ranges from $0.70-1.10 \mathrm{mmol} / \mathrm{L}$ [1] [2]. Serum magnesium levels are a poor reflection of total body stores as only less than $1 \%$ of total body magnesium is found in blood. This is an important consideration when supplementing in clini- 
cal practice [3].

The recommended daily allowance (RDA) for magnesium is $4.5 \mathrm{mg} / \mathrm{Kg} / \mathrm{day}$, or $13 \mathrm{mmol} / \mathrm{day}$ for a $70 \mathrm{~kg}$ individual, with requirements increasing in illness. Magnesium rich foods include seeds, grains, nuts and green vegetables, whilst processed foods tend to lack magnesium. Phytate, fibre and alcohol reduce the absorption of magnesium. Surveys have shown the average Western diet falls short of the RDA [1] [2].

Magnesium is mainly absorbed in the ileum and jejunum [4]. The mechanism of uptake is yet to be fully elucidated, with theories including passive paracellular uptake, passive leak and active extrusion [1] [5] [6].

Plasma magnesium levels are tightly controlled. Whilst the exact mechanism of regulation remains unknown, the renal system plays an essential role. In normal physiology, $80 \%$ of plasma magnesium is filtered, of which 95\% is reabsorbed, leading to 3 - 5 mmols lost in the urine per day. The kidney is able to increase or decrease the urinary magnesium loss dependent on plasma magnesium concentration but the mechanism behind this is unclear [2].

Several hormones are also known to exert influence over magnesium homeostasis. For example, parathyroid hormone (PTH) promotes magnesium reabsorption in the loop of Henle and distal convoluted tubule [7] [8]. It stimulates gut uptake of magnesium and release of magnesium from bones [9].

The incidence of hypomagnesaemia is higher amongst diabetics, and this is correlated with the severity of hyperglycaemia, suggesting a link between insulin and magnesium [10]. In-vitro work has shown increased magnesium uptake in response to insulin in human platelet cells [11]. Studies have produced conflicting results on whether an oral-glucose loading test reduces [1] [12], or causes no change [13], in plasma magnesium in healthy controls.

Insulin's physiological opposite hormone, glucagon, increases magnesium reabsorption in the rat loop of Henle [14] but no change was found in plasma magnesium in humans, in response to intravenous glucagon [15].

These mechanisms are summarised in Figure 1. Table 1 highlights the non-drug and drug causes of hypoand hypermagnasaemia.

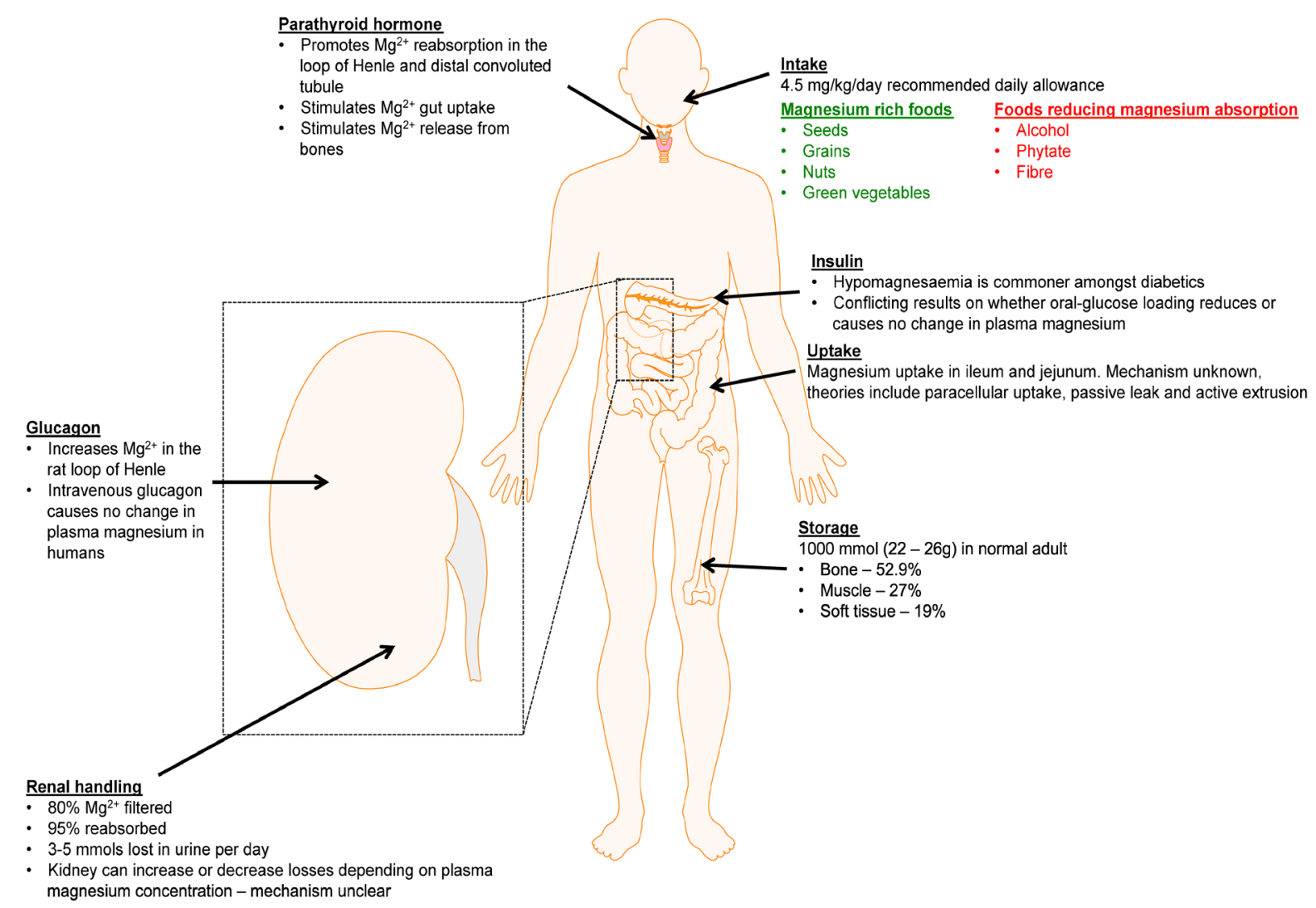

Figure 1. This cartoon illustrates the intake, absorption and regulation of balance of magnesium. Image modified from Motifolio Anatomy Drawing Toolkit available from http://www.motifolio.com/anatomy.html. 
Table 1. This table shows the important non-drug and drug causes of hypo- and hypermagnesaemia. Reference: [70].

\begin{tabular}{cc}
\hline Causes of hypomagnesaemia & Causes of hypermagnesaemia \\
\hline Non-drug causes & Excessive intake \\
Inadequate $\mathrm{Mg}^{2+}$ intake & Renal failure \\
High $\mathrm{Ca}^{2+}$ intake & Hypothyroidism \\
Malabsorption states & Excessive tissue breakdown, e.g. sepsis, shock, burns \\
Gastrointestinal losses, e.g. diarrhoea, vomiting & \\
Polyuria & \\
Parathyroid dysregulation & \\
Bowel resection & \\
Diuretics & Lithium \\
Laxatives & $\mathrm{Mg}^{2+}$ containing antacids (excessive intake) \\
Nephrotoxic drugs & Magnesium containing laxatives \\
\hline
\end{tabular}

\section{Physiological Role of Magnesium}

Magnesium is of fundamental importance to hundreds of physiological processes [1] [16] [17], some of which are shown in Figure 2.

\subsection{Magnesium in Enzymatic Reactions}

Magnesium is a catalyst in enzymatic reactions; either $\mathrm{Mg}^{2+}$ induces a conformational change in the structure of an enzyme, or it can bind to a substrate, for which the enzyme will have a greater affinity [17].

Adenosine triphosphate (ATP) is a cellular "energy currency" used in several processes, such as fat, protein and nucleic acid synthesis. Enzymes responsible for transferring phosphate from adenosine diphosphate (ADP) or ATP are activated by $\mathrm{Mg}^{2+}[17]$.

Magnesium is also crucial in nucleic acid biochemistry. It is a co-factor to restriction endonucleases, exonucleases, polymerases and phosphatases, either as $\mathrm{Mg}^{2+}$ or bound to nucleotide triphosphate (NTP) as Mg-NTP [17].

\subsection{Magnesium's Effect Platelet Activity and Coagulation}

Magnesium inhibited the synthesis and release of pro-aggregation factors cyclooxygenase, lipooxygenase and thromboxane A2 during in-vitro work on human platelets [18]. Human in-vivo studies confirmed the theory, where magnesium infusions were shown to reduce platelet aggregation [19] and increase bleeding time [20]. It would, therefore, be prudent to monitor for signs of bleeding in hypermagnaesmic patients.

In vitro, magnesium enhanced the activity of factor IXa, increased the binding between factors IXa and VIII and together with $\mathrm{Ca}^{2+}$, caused the activation of factor $\mathrm{X}$ [21]. However, the physiological relevance of this remains uncertain as intravenous magnesium did not alter the fibrin-degradation products or antithrombin III complex in human volunteers [22], the INR in human volunteers [23] or the coagulation index in a pre-eclamptic cohort [24].

\subsection{Magnesium in Nucleic Acid Biochemistry}

Magnesium serves as a co-factor to restrict endonucleases, exonucleases, polymerases and phosphatases, either as $\mathrm{Mg}^{2+}$ or bound to nucleotide triphosphate (NTP) as Mg-NTP [17]. 


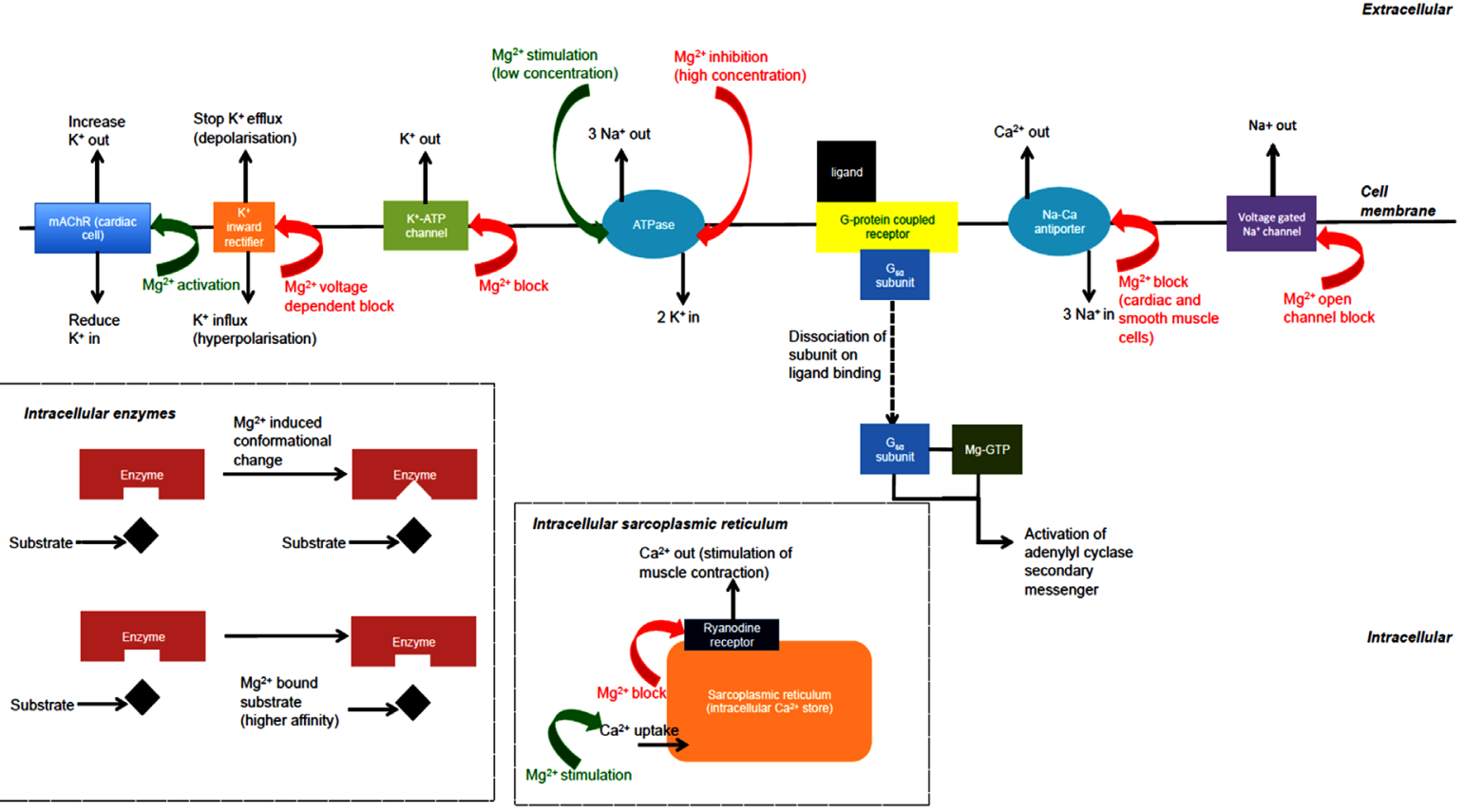

Figure 2. This cartoon illustrates schematically the key mechanisms of how $\mathrm{Mg}^{2+}$ modulates ionic transfer across cell membranes, how $\mathrm{Mg}^{2+}$ acts as a catalyst to intracellular enzymes and its interaction with the sarcoplasmic reticulum to modulate $\mathrm{Ca}^{2+}$ release. Image modified from Motifolio Anatomy Drawing Toolkit available from

http://www.motifolio.com/anatomy.html.

\subsection{Magnesium in Hormone-Receptor Binding}

G-protein coupled receptors are ubiquitous and involved in many organ systems, serving cardiovascular, endocrine, neurological and reproductive functions [25] to name but a few. Upon activation of receptors with the $\mathrm{G}_{\mathrm{s} \alpha}$ subunit, the $\mathrm{G}_{\mathrm{s} \alpha}$ subunit dissociates and binds to magnesium-bound guanosine triphosphate (Mg-GTP), which is responsible for activation of adenylyl cyclase, the second messenger transduction system responsible for hormonal signal transmission [26].

\subsection{Magnesium in Intracellular Calcium Regulation}

Calcium influx into muscle cells triggers release of calcium from its intracellular store, the sarcoplasmic reticulum, via the activation of ryanodine receptors. This stimulates muscle contraction in both cardiac and skeletal muscle [27] [28]. Magnesium blocks this process via inhibition of the ryanodine receptors [27] [28] and it stimulates calcium uptake into the sarcoplasmic reticulum [29]. By competing with calcium binding sites on muscle filaments [30] [31], magnesium acts as a physiological antagonist to calcium [31].

The Na-Ca antiporter is essential in lowering intracellular calcium concentration after depolarisation [32], and this too is modulated by magnesium. $\mathrm{Mg}^{2+}$ inhibits this antiporter via competition with $\mathrm{Ca}^{2+}$ in cardiac cells [33] and smooth muscle cells [34], showing a role for magnesium in regulation of ion transfer across cell membranes.

\subsection{Magnesium in Ionic Transfer across Cell Membranes}

Magnesium is responsible for modulating ionic transfer of sodium or potassium via several pathways [35].

Intracellular $\mathrm{Mg}^{2+}$ causes an open-channel block of voltage-gated sodium channels, blocking the outward sodium current [36], which has been proposed as having a role in modulation of depolarisation [35].

Magnesium plays a role in potassium channels. Many cells contain a potassium inward rectifying channel that is responsible for influx of potassium under hyperpolarisation but stopping efflux under depolarisation. This behaviour is known as inward rectification and is responsible for prolonging depolarisation, which is of relevance in cardiac function and egg fertilisation. The inward rectification is caused by rapid closure of the potassium channel with a voltage-dependent block by intracellular $\mathrm{Mg}^{2+}$ [37]. 
Magnesium further affects inward rectification via modulation of the muscarinic acetylcholine receptor in cardiac cells. Activation of this receptor causes $\mathrm{K}^{+}$efflux and slows pacemaker activity. Depletion of intracellular $\mathrm{Mg}^{2+}$ not only increases the $\mathrm{K}^{+}$efflux but also reduces the $\mathrm{K}^{+}$influx. $\mathrm{Mg}^{2+}$ also participates in the initial activation of the muscarinic potassium channel via G-protein binding [38].

Cardiac muscle, skeletal muscle and insulin-secreting cells exhibit potassium-selective single membrane channels, inhibited by adenosine triphosphate (ATP), known as $\mathrm{K}^{+}$-ATP channels [39] [40]. This $\mathrm{K}^{+}$-ATP channel is blocked by intracellular $\mathrm{Mg}^{2+}$ [41] [42]. In cardiac muscle, this channel is activated under anoxia and causes a shortened plateau of the ventricular action potential and thus reduced contraction. This may be a protective mechanism preventing a dramatic fall in intracellular ATP, critical for cellular processes [40] [43]. In insulin-secreting cells, this channel has a role in initiating insulin release [40]. Its role in skeletal muscle remains unclear [40].

The symptoms of hypomagnesaemia are shown in Table 2.

\section{Pharmacokinetics of Magnesium}

Information on the pharmacology of magnesium is limited. Chuan et al. conducted a pharmacokinetic model, using a population approach, upon a cohort of 116 patients who received magnesium sulphate for pre-eclampsia with measurement of serum magnesium concentration. Their model estimated, along with interpatient variability (co-efficient of variation); a systemic clearance of $4.28 \mathrm{~L} / \mathrm{h}$ (37.3\%), a volume of distribution of $32.3 \mathrm{~L}$ (32.1\%), a baseline concentration of $0.811 \mathrm{mmol} / \mathrm{L}(18.5 \%)$ and a half-life of 5.2 hours [44]. Similar pharmacokinetic modelling by Lu et al. on 51 pre-eclamptic patients given magnesium sulphate estimated a volume of distribution of $24.0 \mathrm{~L}(39 \%)$ [45].

\section{Magnesium as a Drug}

Magnesium’s important therapeutic roles are summarised in Table 3.

\subsection{Magnesium in the Central Nervous System}

Magnesium has been used as a therapeutic agent in acute pain. A recent meta-analysis conducted on twenty randomised trials examined the effect of perioperative intravenous magnesium upon postoperative pain. Magnesium was superior to placebo in reduction of opiate consumption by a mean of $10.52 \mathrm{mg}$ of morphine, as well as a reduction in pain scores at rest and with movement [46]. This may be due to magnesium's role as an NMDAreceptor blocker, similar to ketamine's analgesic properties [47].

There may be a role of magnesium in the treatment of chronic pain. A double-blinded randomised controlled trial found intravenous and oral magnesium therapy in patients with chronic low back pain lowered pain scores and increased range of movement compared to pre-treatment [48].

In long-term care patients with primary insomnia, magnesium, in conjunction with other oral supplements, improved sleep quality, sleep time, ease of getting to sleep, hangover on awakening and alertness the following day [49].

Table 2. This table shows the symptoms of hypomagneaemia. Reference: [71].

\begin{tabular}{ccc}
\hline Range $(\mathbf{m m o l} / \mathbf{L})$ & Range $(\mathbf{m m o l} / \mathbf{L})$ & \multicolumn{1}{c}{ Symptoms } \\
\hline Mild & $0.7-1.0$ & - \\
Moderate & $0.5-0.7$ & Weakness \\
Severe & $<0.5$ & Convulsionscardiac arrhythmias \\
& & ECG changes \\
& & Nystagmus \\
& & Positive Chvostek and Trousseau sign
\end{tabular}


Table 3. This table shows the potential therapeutic uses of magnesium.

\begin{tabular}{|c|c|c|}
\hline System & Condition & Evidence base \\
\hline \multirow[t]{6}{*}{$\begin{array}{l}\text { Central } \\
\text { nervous } \\
\text { system }\end{array}$} & Acute pain & $\begin{array}{l}\text { - Perioperative IV magnesium reduced opiate consumption postoperatively } \\
\text { and led to reduced pain scores [46] }\end{array}$ \\
\hline & Chronic pain & $\begin{array}{l}\text { - IV and PO magnesium increased range of movement and reduced pain } \\
\text { scores in chronic back pain with a neuropathic component [48] }\end{array}$ \\
\hline & Memory dysfunction & $\begin{array}{l}\text { - Increased brain magnesium enhanced learning and memory in rats [72] but } \\
\text { no research in humans to date }\end{array}$ \\
\hline & Neuromuscular blockade & $\begin{array}{l}\text { - Potentiates the effects of non-depolarising neuromuscular blocking agents } \\
\text { - } \quad \text { B } 73]-[76]\end{array}$ \\
\hline & $\begin{array}{l}\text { Postoperative shivering } \\
\text { and thermoregulation }\end{array}$ & $\begin{array}{l}\text { - Reduction in hypothermic shivering threshold from } 36.6^{\circ} \mathrm{C} \text { to } 36.3^{\circ} \mathrm{C} \text { (not } \\
\text { clinically significant) [78], some reports of reduced postoperative shivering } \\
\text { [79]-[81] but not borne out in a systematic review [82] }\end{array}$ \\
\hline & Insomnia & $\begin{array}{l}\text { - PO supplementation gave improved sleep quality, sleep time and ease of } \\
\text { getting to sleep [49] }\end{array}$ \\
\hline \multirow[t]{4}{*}{$\begin{array}{l}\text { Cardiovascular } \\
\text { system }\end{array}$} & Arrhythmias & $\begin{array}{l}\text { - Treatment for torsades de pointes, digoxin toxicity, most atrial and ven- } \\
\text { tricular arrhythmias where hypokalaemia is present [50] } \\
\text { - Superior to amiodarone in cardioversion of atrial tachyarrhythmias in inten- } \\
\text { sive care [51] }\end{array}$ \\
\hline & Myocardial infarction & $\begin{array}{ll}\text { - } & \text { Reduced infarct size in canine model [83] } \\
& \text { LIMIT-2 study showed reduced 28-day mortality in magnesium treated } \\
\text { - } & \text { Lroup [84] } \\
\text { benger and more recent ISIS-4 and MAGIC-2 trials showed no survival } \\
\text { benefit [86] }\end{array}$ \\
\hline & Cardiothoracic surgery & $\begin{array}{l}\text { - Prophylactic magnesium reduced incidence of postoperative atrial fibrilla- } \\
\text { tion from } 28 \% \text { to } 18 \% \text { [53] and ventricular arrhythmias by } 48 \% \text { [54] } \\
\text { - Magnesium in cardioplegic solution reduced postoperative ischaemia [55] }\end{array}$ \\
\hline & Phaeochromocytoma anaesthesia & $\begin{array}{l}\text { - Case series reported } 15 \text { out of } 17 \text { cases with good haemodynamic stability at } \\
\text { induction and tracheal intubation, with } 4 \text { cases requiring additional } \\
\text { pharmacological support for blood pressure control during tumour handling } \\
\text { [59] }\end{array}$ \\
\hline \multirow[t]{2}{*}{$\begin{array}{l}\text { Respiratory } \\
\text { system }\end{array}$} & Acute severe asthma & $\begin{array}{l}\text { - Scottish Intercollegiate Guidelines Network (SIGN) and British Thoracic } \\
\text { Society (BTS) } 2012 \text { recommend intravenous magnesium for patients with } \\
\text { acute asthma, non-respondent to inhaled short-acting beta-2 agonists, in- } \\
\text { haled anticholinergics, corticosteroids and oxygen [60] } \\
\text { - Reduced admission rates in acute severe asthma but not in non-severe [61] }\end{array}$ \\
\hline & Respiratory muscle weakness & $\begin{array}{l}\text { - Improved respiratory muscle power in hypomagnesaemic patients given } \\
\text { supplementation [62] }\end{array}$ \\
\hline $\begin{array}{l}\text { Gastrointestinal } \\
\text { system }\end{array}$ & Mendelson’s syndrome & $\begin{array}{l}\text { - Magnesium trisillicate is superior to cimetidine in achieving a higher gastric } \\
\mathrm{pH} \text { [66] in prophylaxis against Mendelson’s syndrome (pulmonary aspira- } \\
\text { tion of gastric contents in obstetric anaesthesia) }\end{array}$ \\
\hline \multirow[t]{2}{*}{ Obstetrics } & Eclampsia & $\begin{array}{l}\text { - Reduced risk of maternal death and seizure recurrence compared to diaze- } \\
\text { pam [67] }\end{array}$ \\
\hline & Pre-eclampsia & $\begin{array}{l}\text { - Reduced risk of developing eclampsia compared to placebo, phenytoin and } \\
\text { nimodipine [68] }\end{array}$ \\
\hline
\end{tabular}

\subsection{Magnesium in the Cardiovascular System}

Magnesium is established in the treatment of cardiac arrhythmias, particularly torsades de pointes, digoxin toxicity and most atrial and ventricular arrhythmias where hypokalaemia is present [50]. In fact, a randomised control trial showed magnesium sulphate to be superior to amiodarone in cardioversion of atrial tachyarrhythmias in intensive care patients [51].

Serum ionised magnesium is known to fall in patients undergoing cardio-pulmonary bypass [52]. Meta-analyses, have shown a reduction in postoperative atrial fibrillation from $28 \%$ to $18 \%$ with magnesium treatment [53] and a reduced risk of ventricular arrhythmias by 48\% [54] compared to placebo in cardiac surgery. Magnesium in the cardioplegic solution is protective of the myocardium [55] and reduces the incidence of periopera- 
tive ischaemia [56] compared to controls.

Phaeochromocytoma is known to cause cardiovascular instability during induction of anaesthesia, tracheal intubation and tumour handling [50]. Ex-vivo work on cat adrenal glands showed the importance of calcium in co-ordinating catecholamine release from the adrenal gland [57], and it is probably via antagonism of calcium that $\mathrm{Mg}^{2+}$ is able to inhibit adrenal catecholamine release [58]. James discussed the clinical relevance of this in a case series, where magnesium sulphate was used as the primary anti-adrenergic agent in 17 phaeochromocytoma anaesthetics. Catecholamine levels were reduced from time of induction to tumour handling by magnesium sulphate in the 5 cases where measurements were taken. Fifteen of the seventeen cases had good haemodynamic stability at induction and tracheal intubation, with 4 cases requiring additional pharmacological support for blood pressure control during tumour handling [59].

\subsection{Magnesium in the Respiratory System}

The joint Scottish Intercollegiate Guidelines Network (SIGN) and British Thoracic Society (BTS) guidelines of 2012 on the management of asthma recommend intravenous magnesium should be considered for patients with acute asthma, non-respondent to inhaled short-acting beta- 2 agonists, inhaled anticholinergics, corticosteroids and oxygen [60].

A Cochrane review found magnesium therapy was beneficial in reducing admission rates in acute severe asthma, with an improvement in the peak expiratory flow rate. These results were not seen in non-severe acute asthma [61].

Magnesium may have some direct effect upon respiratory muscle power as hypomagnesaemic patients display an improvement in respiratory muscle power when magnesium is replaced [62].

\subsection{Magnesium in the Gastrointestinal System}

Mendelson's syndrome is the pulmonary aspiration of acidic liquid gastric contents intra-operatively or early postoperatively in obstetric anaesthesia, leading to dyspnoea, cyanosis and shock [63] [64]. Antacid therapy has been an established treatment in the prophylaxis against Mendelson's syndrome [65] and magnesium trisillicate is superior to cimetidine in achieving a higher gastric $\mathrm{pH}$ [66].

\subsection{Magnesium in Obstetrics}

Magnesium is efficacious in the termination of seizures associated with eclampsia. A recent Cochrane review showed intravenous or intramuscular magnesium reduced the risk of maternal death and seizure recurrence (risk ratios 0.59 and 0.43 respectively) compared to diazepam. There was no impact on perinatal or neonatal mortality, with fewer babies needing admissions greater than 7 days in the magnesium group [67].

In pre-eclampsia, a Cochrane review showed magnesium reduced the risk of developing eclampsia compared to placebo or no drug therapy in six trials (risk ratio 0.41), and to a lesser extent when compared to phenytoin in three trials (risk ratio 0.08) and nimodipine in one trial (risk ratio 0.33) [68]. It should be noted that rates of progression from pre-eclampsia to eclampsia were as low as 1.9\% in the Magpie trial [69], the largest trial on the matter.

\section{Summary}

Magnesium is fundamental to numerous physiological processes. Physical manifestations of hypomagnesaemia reflect the multitude of systems that depend on this unique electrolyte.

This article discussed magnesium homeostasis, important roles magnesium plays in enzyme interactions, nucleic acid synthesis and facilitating ionic transfer across cell membranes. Overall, the pharmacology of magnesium as a drug is not well known but the clearance, volume of distribution and half-life has been described by modelling data in humans.

Finally, we have discussed established indications for magnesium in the treatment of eclampsia, cardiac dysrhythmias, acute severe asthma and prevention of adrenergic surge in phaeochromocytoma surgery. We have explored more novel applications of magnesium in the prevention of perioperative complications, such as; aspiration in obstetric surgery, postoperative pain and arrhythmias following cardiac surgery.

Magnesium is often overlooked as an electrolyte, which deserves greater appreciation. 


\section{Statement of Conflict of Interest}

None.

\section{References}

[1] Saris, N.E., Mervaala, E., Karppanen, H., Khawaja, J.A. and Lewenstam, A. (2000) Magnesium: An Update on Physiological, Clinical and Analytical Aspects. Clinica Chimica Acta, 294, 1-26. http://dx.doi.org/10.1016/S0009-8981(99)00258-2

[2] Swaminathan, R. (2003) Magnesium Metabolism and Its Disorders. The Clinical Biochemist Reviews, 24, 47-66.

[3] Elin, R.J. (2010) Assessment of Magnesium Status for Diagnosis and Therapy. Magnesium Research, 23, S194-S198.

[4] Dollery, C. (1998) Therapeutic Drugs. 2nd Edition, Churchill Livingstone, London.

[5] Kayne, L.H. and Lee, D.B. (1993) Intestinal Magnesium Absorption. Mineral and Electrolyte Metabolism, 19, 210217.

[6] Beyenbach, K.W. (1990) Transport of Magnesium across Biological Membranes. Magnesium and Trace Elements, 9, 233-254.

[7] Quamme, G.A. (1997) Renal Magnesium Handling: New Insights in Understanding Old Problems. Kidney International, 52, 1180-1195. http://dx.doi.org/10.1038/ki.1997.443

[8] Bailly, C., Roinel, N. and Amiel, C. (1985) Stimulation by Glucagon and PTH of Ca and Mg Reabsorption in the Superficial Distal Tubule of the Rat Kidney. Pflügers Archiv, 403, 28-34. http://dx.doi.org/10.1007/BF00583277

[9] Zofkova, I. and Kancheva, R.L. (1995) The Relationship between Magnesium and Calciotropic Hormones. Magnesium Research, 8, 77-84.

[10] Paolisso, G. and Barbagallo, M. (1997) Hypertension, Diabetes Mellitus, and Insulin Resistance: The Role of Intracellular Magnesium. American Journal of Hypertension, 10, 346-355. http://dx.doi.org/10.1016/S0895-7061(96)00342-1

[11] Hwang, D.L., Yen, C.F. and Nadler, J.L. (1993) Insulin Increases Intracellular Magnesium Transport in Human Platelets. Journal of Clinical Endocrinology \& Metabolism, 76, 549-553.

[12] Corica, F., Allegra, A., Ientile, R., Buemi, M., Corsonello, A., Bonanzinga, S., et al. (1999) Changes in Plasma, Erythrocyte, and Platelet Magnesium Levels in Normotensive and Hypertensive Obese Subjects during Oral Glucose Tolerance Test. American Journal of Hypertension, 12, 128-136. http://dx.doi.org/10.1016/S0895-7061(98)00174-5

[13] Jacomella, V., Sauser, A., Truttmann, A.C., Kuhlmann-Siegenthaler, B.V., Capillo, S. and Bianchetti, M.G. (1997) Free Plasma Magnesium Following Glucose Loading in Healthy Humans. Acta Diabetologica, 34, 235-237. http://dx.doi.org/10.1007/s005920050080

[14] Bailly, C., Roinel, N. and Amiel, C. (1985) Stimulation by Glucagon and PTH of Ca and Mg Reabsorption in the Superficial Distal Tubule of the Rat Kidney. Pflugers Archiv, 403, 28-34. http://dx.doi.org/10.1007/BF00583277

[15] Rossier, M.C., Truttmann, A.C., von Vigier, R.O., Stoffel, P.B. and Bianchetti, M.G. (1999) Free and Total Circulating Magnesium Following Glucagon Injection in Humans. Magnesium Research, 12, 175-179.

[16] Altura, B.M. (1994) Introduction: Importance of Mg in Physiology and Medicine and the Need for Ion Selective Electrodes. Scandinavian Journal of Clinical and Laboratory Investigation Supplementum, 217, 5-9. http://dx.doi.org/10.3109/00365519409095206

[17] Cowan, J.A. (2002) Structural and Catalytic Chemistry of Magnesium-Dependent Enzymes. Biometals, 15, $225-235$. http://dx.doi.org/10.1023/A:1016022730880

[18] Hwang, D.L., Yen, C.F. and Nadler, J.L. (1992) Effect of Extracellular Magnesium on Platelet Activation and Intracellular Calcium Mobilization. American Journal of Hypertension, 5, 700-706.

[19] Gawaz, M., Ott, I., Reininger, A.J. and Neumann, F.J. (1994) Effects of Magnesium on Platelet Aggregation and Adhesion. Magnesium Modulates Surface Expression of Glycoproteins on Platelets in Vitro and ex Vivo. Thrombosis and Haemostasis, 72, 912-918.

[20] Ravn, H.B., Vissinger, H., Kristensen, S.D., Wennmalm, A., Thygesen, K. and Husted, S.E. (1996) Magnesium Inhibits Platelet Activity-An Infusion Study in Healthy Volunteers. Thrombosis and Haemostasis, 75, 939-944.

[21] Sekiya, F., Yoshida, M., Yamashita, T. and Morita, T. (1996) Magnesium(II) Is a Crucial Constituent of the Blood Coagulation Cascade. Potentiation of Coagulant Activities of Factor IX by $\mathrm{Mg}^{2+}$ Ions. Journal of Biological Chemistry, 271, 8541-8544. http://dx.doi.org/10.1074/jbc.271.15.8541

[22] Ravn, H.B., Lassen, J.F., Bergenhem, N. and Kristensen, A.T. (2001) Intravenous Magnesium Does Not Influence the Activity of the Coagulation Cascade. Blood Coagulation \& Fibrinolysis, 12, 223-228. http://dx.doi.org/10.1097/00001721-200106000-00001 
[23] Ames, W.A., McDonnell, N. and Potter, D. (1999) The Effect of Ionised Magnesium on Coagulation Using Thromboelastography. Anaesthesia, 54, 999-1001. http://dx.doi.org/10.1046/j.1365-2044.1999.00647.x

[24] Harnett, M.J., Datta, S. and Bhavani-Shankar, K. (2001) The Effect of Magnesium on Coagulation in Parturients with Preeclampsia. Anesthesia \& Analgesia, 92, 1257-1260. http://dx.doi.org/10.1097/00000539-200105000-00033

[25] Katritch, V., Cherezov, V. and Stevens, R.C. (2013) Structure-Function of the G Protein-Coupled Receptor Superfamily. Annual Review of Pharmacology and Toxicology, 53, 531-556. http://dx.doi.org/10.1146/annurev-pharmtox-032112-135923

[26] Birnbaumer, L. and Zurita, A.R. (2010) On the Roles of Mg in the Activation of G Proteins. Journal of Receptors and Signal Transduction, 30, 372-375. http://dx.doi.org/10.3109/10799893.2010.508165

[27] Laver, D.R., Baynes, T.M. and Dulhunty, A.F. (1997) Magnesium Inhibition of Ryanodine-Receptor Calcium Channels: Evidence for Two Independent Mechanisms. The Journal of Membrane Biology, 156, 213-229. http://dx.doi.org/10.1007/s002329900202

[28] Gusev, K. and Niggli, E. (2008) Modulation of the Local SR Ca ${ }^{2+}$ Release by Intracellular $\mathrm{Mg}^{2+}$ in Cardiac Myocytes. Journal of General Physiology, 132, 721-730. http://dx.doi.org/10.1085/jgp.200810119

[29] Stephenson, E.W. and Podolsky, R.J. (1977) Regulation by Magnesium of Intracellular Calcium Movement in Skinned Muscle Fibers. Journal of General Physiology, 69, 1-16. http://dx.doi.org/10.1085/jgp.69.1.1

[30] Podolsky, R.J. and Costantin, L.L. (1964) Regulation by Calcium of the Contraction and Relaxation of Muscle Fibers. Federation Proceedings, 23, 933-939.

[31] Iseri, L.T. and French, J.H. (1984) Magnesium: Nature’s Physiologic Calcium Blocker. American Heart Journal, 108, 188-193. http://dx.doi.org/10.1016/0002-8703(84)90572-6

[32] Kiedrowski, L., Brooker, G., Costa, E. and Wroblewski, J.T. (1994) Glutamate Impairs Neuronal Calcium Extrusion While Reducing Sodium Gradient. Neuron, 12, 295-300. http://dx.doi.org/10.1016/0896-6273(94)90272-0

[33] Ledvora, R.F. and Hegyvary, C. (1983) Dependence of $\mathrm{Na}^{+}-\mathrm{Ca}^{2+}$ Exchange and $\mathrm{Ca}^{2+}-\mathrm{Ca}^{2+}$ Exchange on Monovalent Cations. Biochimica et Biophysica Acta (BBA), Biomembranes, 729, 123-136. http://dx.doi.org/10.1016/0005-2736(83)90463-7

[34] Smith, J.B., Cragoe, E.J. and Smith Jr., L. (1987) $\mathrm{Na}^{+} / \mathrm{Ca}^{2+}$ Antiport in Cultured Arterial Smooth Muscle Cells. Inhibition by Magnesium and Other Divalent Cations. Journal of Biological Chemistry, 262, 11988-11994.

[35] Bara, M., Guiet-Bara, A. and Durlach, J. (1993) Regulation of Sodium and Potassium Pathways by Magnesium in Cell Membranes. Magnesium Research, 6, 167-177.

[36] Pusch, M. (1990) Open-Channel Block of $\mathrm{Na}^{+}$Channels by Intracellular $\mathrm{Mg}^{2+}$. European Biophysics Journal, 18, 317326. http://dx.doi.org/10.1007/BF00196922

[37] Matsuda, H., Saigusa, A. and Irisawa, H. (1987) Ohmic Conductance through the Inwardly Rectifying K Channel and Blocking by Internal $\mathrm{Mg}^{2+}$. Nature, 325, 156-159. http://dx.doi.org/10.1038/305147a0

[38] Horie, M. and Irisawa, H. (1989) Dual Effects of Intracellular Magnesium on Muscarinic Potassium Channel Current in Single Guinea-Pig Atrial Cells. Journal of Physiology, 408, 313-332.

[39] Noma, A. (1983) ATP-Regulated $\mathrm{K}^{+}$Channels in Cardiac Muscle. Nature, 305, 147-148. http://dx.doi.org/10.1038/305147a0

[40] Ashcroft, F.M. (1988) Adenosine 5'-Triphosphate-Sensitive Potassium Channels. Annual Review of Neuroscience, 11, 97-118. http://dx.doi.org/10.1146/annurev.ne.11.030188.000525

[41] Ashcroft, F.M. and Kakei, M. (1989) ATP-Sensitive $\mathrm{K}^{+}$Channels in Rat Pancreatic Beta-Cells: Modulation by ATP and $\mathrm{Mg}^{2+}$ Ions. Journal of Physiology, 416, 349-367.

[42] Horie, M, Irisawa, H. and Noma, A. (1987) Voltage-Dependent Magnesium Block of Adenosine-Triphosphate-Sensitive Potassium Channel in Guinea-Pig Ventricular Cells. Journal of Physiology, 387, 251-272.

[43] Noma, A. and Shibasaki, T. (1985) Membrane Current through Adenosine-Triphosphate-Regulated Potassium Channels in Guinea-Pig Ventricular Cells. Journal of Physiology, 363, 463-480.

[44] Chuan, F.S., Charles, B.G., Boyle, R.K. and Rasiah, R.L. (2001) Population Pharmacokinetics of Magnesium in Preeclampsia. American Journal of Obstetrics \& Gynecology, 185, 593-599. http://dx.doi.org/10.1067/mob.2001.116726

[45] Lu, J., Pfister, M., Ferrari, P., Chen, G. and Sheiner, L. (2002) Pharmacokinetic-Pharmacodynamic Modelling of Magnesium Plasma Concentration and Blood Pressure in Preeclamptic Women. Clinical Pharmacokinetics, 41, 1105-1113. http://dx.doi.org/10.2165/00003088-200241130-00007

[46] De Oliveira Jr., G.S., Castro-Alves, L.J., Khan, J.H. and McCarthy, R.J. (2013) Perioperative Systemic Magnesium to Minimize Postoperative Pain: A Meta-Analysis of Randomized Controlled Trials. Anesthesiology, 119, 178-190. http://dx.doi.org/10.1097/ALN.0b013e318297630d 
[47] Tramer, M.R., Schneider, J., Marti, R.A. and Rifat, K. (1996) Role of Magnesium Sulfate in Postoperative Analgesia. Anesthesiology, 84, 340-347. http://dx.doi.org/10.1097/00000542-199602000-00011

[48] Yousef, A.A. and Al-Deeb, A.E. (2013) A Double-Blinded Randomised Controlled Study of the Value of Sequential Intravenous and Oral Magnesium Therapy in Patients with Chronic Low Back Pain with a Neuropathic Component. Anaesthesia, 68, 260-266. http://dx.doi.org/10.1111/anae.12107

[49] Rondanelli, M., Opizzi, A., Monteferrario, F., Antoniello, N., Manni, R. and Klersy, C. (2011) The Effect of Melatonin, Magnesium, and Zinc on Primary Insomnia in Long-Term Care Facility Residents in Italy: A Double-Blind, PlaceboControlled Clinical Trial. Journal of the American Geriatrics Society, 59, 82-90. http://dx.doi.org/10.1111/j.1532-5415.2010.03232.x

[50] Fawcett, W.J., Haxby, E.J. and Male, D.A. (1999) Magnesium: Physiology and Pharmacology. British Journal of Anaesthesia, 83, 302-320. http://dx.doi.org/10.1093/bja/83.2.302

[51] Moran, J.L., Gallagher, J., Peake, S.L., Cunningham, D.N., Salagaras, M. and Leppard, P. (1995) Parenteral Magnesium Sulfate versus Amiodarone in the Therapy of Atrial Tachyarrhythmias: A Prospective, Randomized Study. Critical Care Medicine, 23, 1816-1824. http://dx.doi.org/10.1097/00003246-199511000-00005

[52] Brookes, C.I. and Fry, C.H. (1993) Ionised Magnesium and Calcium in Plasma from Healthy Volunteers and Patients Undergoing Cardiopulmonary Bypass. British Heart Journal, 69, 404-408. http://dx.doi.org/10.1136/hrt.69.5.404

[53] Miller, S., Crystal, E., Garfinkle, M., Lau, C., Lashevsky, I. and Connolly, S.J. (2005) Effects of Magnesium on Atrial Fibrillation after Cardiac Surgery: A Meta-Analysis. Heart, 91, 618-623. http://dx.doi.org/10.1136/hrt.2004.033811

[54] Shiga, T., Wajima, Z., Inoue, T. and Ogawa, R. (2004) Magnesium Prophylaxis for Arrhythmias after Cardiac Surgery: A Meta-Analysis of Randomized Controlled Trials. The American Journal of Medicine, 117, 325-333. http://dx.doi.org/10.1016/j.amjmed.2004.03.030

[55] Hearse, D.J., Stewart, D.A. and Braimbridge, M.V. (1978) Myocardial Protection during Ischemic Cardiac Arrest. The Importance of Magnesium in Cardioplegic Infusates. Journal of Thoracic and Cardiovascular Surgery, 75, 877-885.

[56] Shakerinia, T., Ali, I.M. and Sullivan, J.A. (1996) Magnesium in Cardioplegia: Is It Necessary? Canadian Journal of Surgery, 39, 397-400.

[57] Douglas, W.W. and Rubin, R.P. (1963) The Mechanism of Catecholamine Release from the Adrenal Medulla and the Role of Calcium in Stimulus-Secretion Coupling. Journal of Physiology, 167, 288-310.

[58] Rubin, R.P., Feinstein, M.B., Jaanus, S.D. and Paimre, M. (1967) Inhibition of Catecholamine Secretion and Calcium Exchange in Perfused Cat Adrenal Glands by Tetracaine and Magnesium. Journal of Pharmacology and Experimental Therapeutics, 155, 463-471.

[59] James, M.F. (1989) Use of Magnesium Sulphate in the Anaesthetic Management of Phaeochromocytoma: A Review of 17 Anaesthetics. British Journal of Anaesthesia, 62, 616-623. http://dx.doi.org/10.1093/bja/62.6.616

[60] British Thoracic Society (2012) Scottish Intercollegiate Guidelines Network. British Guideline on the Management of Asthma, 117.

[61] Rowe, B.H., Bretzlaff, J.A., Bourdon, C., Bota, G.W. and Camargo Jr., C.A. (2000) Magnesium Sulfate for Treating Exacerbations of Acute Asthma in the Emergency Department. Cochrane Database of Systematic Reviews, Article ID: CD001490.

[62] Dhingra, S., Solven, F., Wilson, A. and McCarthy, D.S. (1984) Hypomagnesemia and Respiratory Muscle Power. American Review of Respiratory Disease, 129, 497-498.

[63] Mendelson, C.L. (1946) The Aspiration of Stomach Contents into the Lungs during Obstetric Anesthesia. American Journal of Obstetrics \& Gynecology, 52, 191-205.

[64] Berris, B. and Kasler, D. (1965) Pulmonary Aspiration of Gastric Acid-Mendelson’s Syndrome. Canadian Medical Association Journal, 92, 905-907.

[65] Husemeyer, R.P., Davenport, H.T. and Rajasekaran, T. (1978) Cimetidine as a Single Oral Dose for Prophylaxis against Mendelson’s Syndrome. Anaesthesia, 33, 775-778. http://dx.doi.org/10.1111/j.1365-2044.1978.tb08492.x

[66] Husemeyer, R.P. and Davenport, H.T. (1980) Prophylaxis for Mendelson’s Syndrome before Elective Caesarean Section. A Comparison of Cimetidine and Magnesium Trisilicate Mixture Regimens. BJOG: An International Journal of Obstetrics \& Gynaecology, 87, 565-570. http://dx.doi.org/10.1111/j.1471-0528.1980.tb05004.x

[67] Duley, L., Henderson-Smart, D.J., Walker, G.J. and Chou, D. (2010) Magnesium Sulphate versus Diazepam for Eclampsia. Cochrane Database of Systematic Reviews, Article ID: CD000127.

[68] Duley, L., Gulmezoglu, A.M., Henderson-Smart, D.J. and Chou, D. (2010) Magnesium Sulphate and Other Anticonvulsants for Women with Pre-Eclampsia. Cochrane Database of Systematic Reviews, Article ID: CD000025.

[69] Altman, D., Carroli, G., Duley, L., Farrell, B., Moodley, J., Neilson, J., et al. (2002) Do Women with Pre-Eclampsia, and Their Babies, Benefit from Magnesium Sulphate? The Magpie Trial: A Randomised Placebo-Controlled Trial. The 
Lancet, 359, 1877-1890. http://dx.doi.org/10.1016/S0140-6736(02)08778-0

[70] Bringhurst, F.R., Demay, M.B., Krane, S.M. and Kronenberg, H.M. (2005) Bone and Mineral Metabolism in Health and Disease. In: Kasper, D.L., Braunwald, E., Hauser, S., Longo, D., Jameson, J.L. and Fauci, A.S., Eds., Harrison's Principles of Internal Medicine, 16th Edition, McGraw-Hill, New York.

[71] Whang, R., Hampton, E.M. and Whang, D.D. (1994) Magnesium Homeostasis and Clinical Disorders of Magnesium Deficiency. Annals of Pharmacotherapy, 28, 220-226.

[72] Slutsky, I., Abumaria, N., Wu, L.J., Huang, C., Zhang, L., Li, B., et al. (2010) Enhancement of Learning and Memory by Elevating Brain Magnesium. Neuron, 65, 165-177. http://dx.doi.org/10.1016/j.neuron.2009.12.026

[73] Sinatra, R.S., Philip, B.K., Naulty, J.S. and Ostheimer, G.W. (1985) Prolonged Neuromuscular Blockade with Vecuronium in a Patient Treated with Magnesium Sulfate. Anesthesia \& Analgesia, 64, 1220-1222. http://dx.doi.org/10.1213/00000539-198512000-00019

[74] Fuchs-Buder, T., Wilder-Smith, O.H., Borgeat, A. and Tassonyi, E. (1995) Interaction of Magnesium Sulphate with Vecuronium-Induced Neuromuscular Block. British Journal of Anaesthesia, 74, 405-409. http://dx.doi.org/10.1093/bja/74.4.405

[75] Fuchs-Buder, T. and Tassonyi, E. (1996) Magnesium Sulphate Enhances Residual Neuromuscular Block Induced by Vecuronium. British Journal of Anaesthesia, 76, 565-566. http://dx.doi.org/10.1093/bja/76.4.565

[76] Pinard, A.M., Donati, F., Martineau, R., Denault, A.Y., Taillefer, J. and Carrier, M. (2003) Magnesium Potentiates Neuromuscular Blockade with Cisatracurium during Cardiac Surgery. Canadian Journal of Anaesthesia, 50, 172-178. http://dx.doi.org/10.1007/BF03017852

[77] James, M.F., Cork, R.C. and Dennett, J.E. (1986) Succinylcholine Pretreatment with Magnesium Sulfate. Anesthesia \& Analgesia, 65, 373-376. http://dx.doi.org/10.1213/00000539-198604000-00012

[78] Wadhwa, A., Sengupta, P., Durrani, J., Akca, O., Lenhardt, R., Sessler, D.I., et al. (2005) Magnesium Sulphate Only Slightly Reduces the Shivering Threshold in Humans. British Journal of Anaesthesia, 94, 756-762. http://dx.doi.org/10.1093/bja/aei105

[79] Beliaev, A.V., Ryzhin, S.M. and Dubov, A.M. (1991) Use of Magnesium Sulfate for Controlling Postoperative Shivering. KlinKhir, 3, 42-44.

[80] Miyakawa, H., Matsumoto, K., Matsumoto, S., Mori, M., Yoshitake, S., Noguchi, T., et al. (1991) A Comparison of Three Drugs (Pethidine, Magnesium Sulfate and Droperidol) in Patients with Post-Anesthesia Shivering. Masui, 40, 1503-1506.

[81] Kizilirmak, S., Karakas, S.E., Akca, O., Ozkan, T., Yavru, A., Pembeci, K., et al. (1997) Magnesium Sulfate Stops Postanesthetic Shivering. Annals of the New York Academy of Sciences, 813, 799-806. http://dx.doi.org/10.1111/j.1749-6632.1997.tb51784.x

[82] Kranke, P., Eberhart, L.H., Roewer, N. and Tramer, M.R. (2002) Pharmacological Treatment of Postoperative Shivering: A Quantitative Systematic Review of Randomized Controlled Trials. Anesthesia \& Analgesia, 94, 453-460.

[83] Christensen, C.W., Rieder, M.A., Silverstein, E.L. and Gencheff, N.E. (1995) Magnesium Sulfate Reduces Myocardial Infarct Size When Administered before but Not after Coronary Reperfusion in a Canine Model. Circulation, 92, 26172621. http://dx.doi.org/10.1161/01.CIR.92.9.2617

[84] Woods, K.L., Fletcher, S., Roffe, C. and Haider, Y. (1992) Intravenous Magnesium Sulphate in Suspected Acute Myocardial Infarction: Results of the Second Leicester Intravenous Magnesium Intervention Trial (LIMIT-2). The Lancet, 339, 1553-1558. http://dx.doi.org/10.1161/01.CIR.92.9.2617

[85] ISIS-4 (Fourth International Study of Infarct Survival) Collaborative Group (1995) A Randomised Factorial Trial Assessing Early Oral Captopril, Oral Mononitrate, and Intravenous Magnesium Sulphate in 58,050 Patients with Suspected Acute Myocardial Infarction. The Lancet, 345, 669-685. http://dx.doi.org/10.1016/S0140-6736(95)90865-X

[86] Magnesium in Coronaries (MAGIC) Trial Investigators (2002) Early Administration of Intravenous Magnesium to High-Risk Patients with Acute Myocardial Infarction in the Magnesium in Coronaries (MAGIC) Trial: A Randomised Controlled Trial. The Lancet, 360, 1189-1196. http://dx.doi.org/10.1016/S0140-6736(02)11278-5 
Scientific Research Publishing (SCIRP) is one of the largest Open Access journal publishers. It is currently publishing more than 200 open access, online, peer-reviewed journals covering a wide range of academic disciplines. SCIRP serves the worldwide academic communities and contributes to the progress and application of science with its publication.

Other selected journals from SCIRP are listed as below. Submit your manuscript to us via either submit@scirp.org or Online Submission Portal.
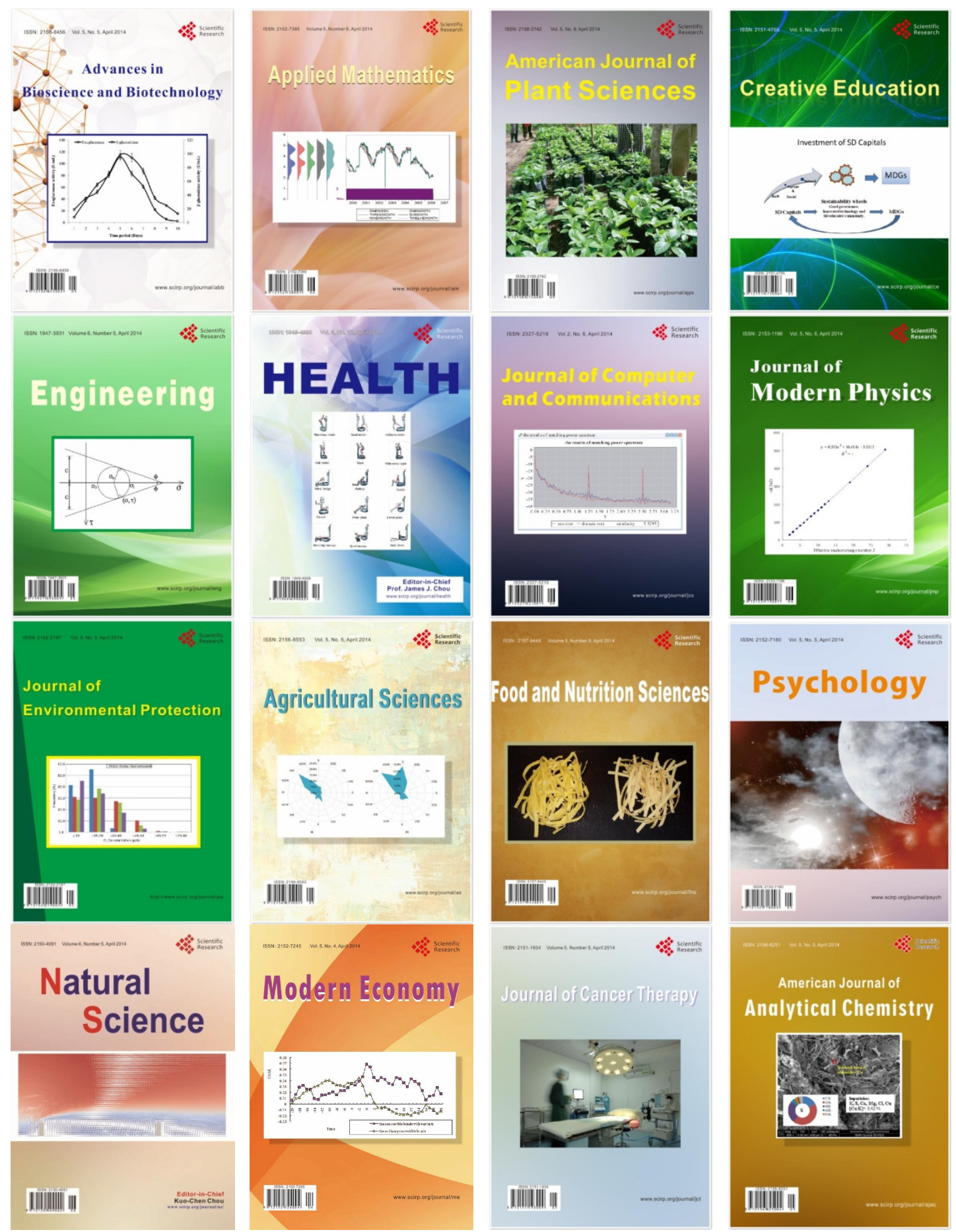